\title{
EFL Students' Needs for Improving Their Writing Skills
}

Osama Albashir Jamoom ${ }^{1 *}$

${ }^{1}$ Department of English, Faculty of Arts, University of Zawia, Libya

DOI: $10.36348 /$ sijll.2021.v04i04.004

| Received: 17.03.2021 | Accepted: 22.04.2021 | Published: 30.04.2021

*Corresponding author: Osama Albashir Jamoom

\section{Abstract}

This study employed needs analysis approach to investigate EFL students' needs to improve their writing skills. The data were collected from 28 EFL undergraduate students studying at the Department of English, Faculty of Arts, University of Zawia through the modality of questionnaire. The results suggested that the students believed that improving their writing skills is significant for their current study and their future career. The results also revealed that students needed to improve most of their writing skills and extending their knowledge about the writing aspects including content, organization, vocabulary, grammar, mechanics and others. These results implied that the students had limited knowledge of the necessary writing aspects, and they suffered lack of practicing writing in and outside their classrooms. Understanding the students' needs to improve their writing skills, the study ended with suggestions and recommendations that might contribute in improving students' writing skills.

Keywords: Writing Skills, Needs Analysis, Students' Writing Needs.

Copyright (C) 2021 The Author(s): This is an open-access article distributed under the terms of the Creative Commons Attribution 4.0 International License (CC BY-NC 4.0) which permits unrestricted use, distribution, and reproduction in any medium for non-commercial use provided the original author and source are credited.

\section{INTRODUCTION}

Writing is a productive skill that requires students to produce messages and ideas through written texts. It has been considered as one of the significant skills students need to improve for their academic success Gillett et al., [1, 2]. "Learning to write in a foreign language or second language mainly involves linguistic knowledge and vocabulary choices, syntactic patterns and cohesive devices that comprise the essential blocks of texts" Hyland [3]. This supports the idea that learning to write is a hard work for EFL/ESL students as it requires students' skills, knowledge and proficiency in a number of areas. Thus, teachers and course designers, before starting any writing course, are demanded to identify the areas and skills that students need to improve in order to be good writers. This can be achieved by employing needs analysis approach.

Needs analysis approach is defined as "a systematic and on-going process of gathering information about students' needs and preferences, interpreting this information and then making course decisions based on the interpretation in order to meet the needs" Grave [4]. Information about students' writing needs is essential for teachers and course designers to arrange writing courses that meet these needs and participate in the improvement of the students' writing skills Dudley-Evans \& St. John [5,6].
It is also required for developing the objectives of the writing courses and evaluating the content of these courses. Moreover, this information is an important factor that teachers must consider for choosing appropriate teaching material and adopting effective teaching methods and approaches that cover their students' lacks and overcome their deficiencies [7, 8]. In other words, needs analysis approach is utilised by teachers and course designers as starting point of any language programme to determine students' learning needs. The obtained data about the students' needs are used as the base for setting the objectives of this programme and arranging syllabuses that respond to the students' learning needs.

Since determining students' writing needs is a starting point for developing the students' writing skills, this study intended to employ needs analysis approach within an EFL context to investigate students' writing needs. It examined the writing activities students have done and explored students' perceptions of their needs to improve their writing skills. The results of this investigation would be beneficial for teachers and writing courses designers to organise and structure writing courses that contribute to the improvement of EFL students' writing skills. 
Osama Albashir Jamoom., Sch Int J Linguist Lit, Apr, 2021; 4(4): 106-111

\section{LITERATUR REVIEW \\ Writing as a Language Skill}

Beside its function as a medium of communication, writing is a significant productive skill that enhances ESL/ EFL students' language learning and acquisition. It assists them in recalling and recognizing what they have learned as well as monitoring their progress in language learning $[9,10]$. It also reinforces students' learning of new grammatical structures, idioms and words that they have just learned Raimes [11]. Besides, writing supports students' intellectual growth and expands their cognitive domain as well as enhancing their language skills. Thus, scholars recommend that writing should be included as a part of any language course e.g. [11].

However, writing has been argued to be a challenging task in both the mother tongue and the second/ foreign language because it requires skills and knowledge in a number of areas. In order to produce a text that achieves the requirements of writing, students are demanded to employ not only their knowledge of the writing process (i.e. planning, drafting, revising and editing), but also their knowledge of the topic they are writing about [12].They are also expected to exploit their knowledge of syntax, grammar, mechanics and word choice of the written texts Tribble [13]. Moreover, they need to utilize their knowledge of social context, audience, conventions and style of genre and their experience and expectation of the discourse community [14]. These challenges imply that a writer deals with different features of writing to produce a clear effective written text. According to Heaton [15] these features are:

- Language use: the ability to write correct and appropriate sentences;

- Mechanical Skills: the ability to use correctly those conventions peculiar to written language, e.g. punctuations and spelling;

- Treatment of Content: the ability to think creatively and develop thoughts, excluding all irrelevant information;

- Stylistic skills: the ability to manipulate sentences and paragraphs and use language effectively;

- Judgment skills: the ability to write in an appropriate manner for appropriate purpose with a particular audience (p.135).

Taken together, writing is not just arranging words into correct grammatical sentences and linking these sentences to form written texts as many EFL students think. It is "the act of thinking, composing, and encoding language into such text; these acts also necessarily entail discourse interactions within a sociocultural context" Cumming [16]. It needs students' conscious mental efforts which should be supported over time by training and practice $([17,18,19]$. Briefly, writing is a complex skill that has many different features, involving the interaction of student writers' knowledge, proficiency and skills in several areas.

Accordingly, teachers of writing and course designers play crucial roles for helping students improve their writing skills. They need to investigate the students' needs for improving their writing skills as this would help them to adopt teaching methods and design writing courses that suit the students' needs. Knowledge about the students' needs can be gained by utilising needs analysis approach

\section{Needs Analysis}

Needs analysis is a significant instrument for reviewing, evaluating and developing any language programme e.g. $[5,6]$. It is divided into students' necessities (what students need to learn), students' lacks (what students' problems throughout learning) and students' wants (what students wish to learn) [20]. Needs analysis can be used to make connection between students' current academic learning and their future needs, and this connection would assist to determine the differences between the desired conditions (ideal conditions) with the existing conditions (real conditions) [21]. That is to say, employing needs analysis approach is significant for the success of any language course. This approach can be used by teachers and course designers to collect data about students' current competence of the target language and skills and knowledge that students need to acquire and develop during the language course. These data serve as the basis for setting the objectives and the requirements of the language course as well as preparing and developing the curriculum, the materials and the learning activities of that course [22].

Many research studies have applied the needs analysis approach to understand students' needs of English for Academic Purposes (EAP) and few of them analyse writing skills needs of EFL students. One of them was done by Hyland (1997) who used a questionnaire to survey students' needs of EAP from eight disciplines at five Hong Kong tertiary institutions. The results of this study revealed that EAP was valued by the student participants and was regarded as an important tool for their academic success. They also demonstrated that the students' language needs are varied according to their proficiency level, discipline and year of study. These results signified that knowledge of students' needs is a fundamental element for developing their language skills.

Correspondingly, Cai \& Kong [23] used the needs analysis approach to identify the needs of postgraduate Chinese students who was attending English for academic purpose course. The main objectives of this study were improving the students' writing skills and evaluating the quality of their academic writing course. The findings demonstrated that most of the students had never attended an 
Osama Albashir Jamoom., Sch Int J Linguist Lit, Apr, 2021; 4(4): 106-111

academic writing course before, and they needed to improve many academic writing skills that never been taught to them. The results implied that students need writing courses that focus on "generic features for writing the sections in a research article/ thesis and, more importantly, the linguistic resources needed for writing academic papers appropriately" [23].

Although, many research studies have investigated ESL/EFL students' needs for improving their language skills in different contexts, few of them have examined the EFL undergraduate students' needs to improve their writing skills. Therefore, this study intended to employ the needs analysis approach for investigating EFL undergraduate students' needs for improve their writing skills. To achieve these goals, these research questions are formed:

i. What are EFL students' perceptions of the importance of developing their writing skills to their current studies and future career?

ii. In their own perceptions, what are the writing skills students need to improve to be good writers?

\section{METHOD}

\section{Participants and Context}

This research study took place at the Department of English, Faculty of Arts, University of Zawia, Libya. This department offers a BA degree programme in Applied Linguistics and Translation. This programme aims to facilitate students' professional knowledge in the field of teaching English and Translation. At the Department of English, students are required to study for eight semesters (full-time), and they must study English as a foreign language through a variety of compulsory courses. During that journey, they are required to study eight mandatory courses of writing. The main objective of these courses is qualifying students to write different types of academic paragraphs, different types of short and long academic essays, short stories and a short academic research paper. However, the students of the department, upon graduation, are still struggling to write simple paragraphs and essays.

The student participants who were studying at the fifth semester were 28,10 males and 18 females. All of them are Libyan, and their native language is Arabic. Their ages ranged from 19 to 24 . Before joining the Department of English, these students studied general English for 6 years in their secondary schools.

\section{Data Collection and Analysis}

Data of this study were collected by using an online version of a questionnaire which was sent to the fifth semester students studying at Department of English. The items of the questionnaire were created on the basis of the literature review. All the items of the questionnaire are Likert scale because they are suitable to elicit the students' perspectives of the writing skills that they need to develop. The questionnaire was piloted with 5 fifth semester students studying at the department. Wording, length and organization of some items of the questionnaire were revised in line with their feedback. The last version of the questionnaire has four sections which address the research questions. The first section asks students about the importance of developing their writing skills to their current studies and their future careers. The second one asks students about the writing tasks that they are required to perform during their study at the department. The third section investigates the students' perceptions of the writing skills that they need to improve. The last section was devoted to collect demographic data about the student participants.

Descriptive statistics were employed to analyze the questionnaire data. This type of statistics measured the central tendency and variability (i.e. mean scores and standard deviations) of the students' responses to the questionnaire items. These statistics were presented and displayed into tables.

\section{RESULTS \& DISCUSSION}

\section{Students' beliefs about the importance of Writing}

The first section of the questionnaire intended to identify the students' beliefs about the importance of writing skill. The students were asked to indicate on a 5-point scale how important writing skill to their current studies and future careers. Table 1 shows that the mean scores for the two items asking students about the importance of writing skill for their current study $(\mathrm{M}=4.53, \mathrm{SD}=074)$ and future careers $(\mathrm{M}=4.46$, $\mathrm{SD}=0.69)$ are very high. These results are on line with the findings of Evans \& Green [23-24] who found that EFL students consider academic writing as a pivotal skill for their academic study. The results suggest that the student participants are aware of the close connection between developing their writing skills and their success in their current study and in their future academic careers. The students' beliefs could be attributed to their personal goals and motivation to succeed in their study and having highly successful future careers [25]. The students' positive perceptions about the importance of writing indicate that they are willing to improve their writing skills. Their perceptions might influence their attitudes and behaviour towards developing their writing skills. 
Osama Albashir Jamoom., Sch Int J Linguist Lit, Apr, 2021; 4(4): 106-111

Table-1: Students' Beliefs about the Importance of Writing

\begin{tabular}{|l|l|l|l|l|}
\hline \multicolumn{2}{|c|}{} & $\begin{array}{l}\text { Mean } \\
\text { (M) }\end{array}$ & $\begin{array}{l}\text { Standard } \\
\text { Deviation } \\
\text { (SD) }\end{array}$ & $\begin{array}{l}\text { Number of } \\
\text { Participants (N) }\end{array}$ \\
\hline 1 & $\begin{array}{l}\text { How important do you think writing skill are to your current } \\
\text { graduate studies? }\end{array}$ & 4.53 & 0.74 & 28 \\
\hline 2 & How important do you think writing skill are to your future career? & 4.46 & 0.69 & 28 \\
\hline
\end{tabular}

\section{Writing Tasks Students Required to be performed}

The second section of the questionnaire attempted to reveal the writing tasks that the student participants had done during their writing courses. The students' responses to the items of this section might reflect the students' writing competences. Table 2 depicts that the mean values of students writing different types of sentences $(\mathrm{M}=3.96, \mathrm{SD}=0.99)$ and writing different types of paragraphs $(\mathrm{M}=3.64, \mathrm{SD}=$ 1.28) are somehow high. These results suggest that most students have involved in writing sentences and paragraphs. Moreover, the middle mean values are found in students writing CVs $(\mathrm{M}=2.85, \mathrm{SD}=1.5)$, students writing letters $(\mathrm{M}=2.5, \quad \mathrm{SD}=1.31)$ and summarizing articles $(\mathrm{M}=2.28, \mathrm{SD}=1.48)$. These findings indicate that about half of the students did these writing activities during their writing courses. What is surprising is that the lowest mean scores were recorded to students writing different types of essays $(\mathrm{M}=1.82, \quad \mathrm{SD}=0.9)$ and students writing reports $(\mathrm{M}=1.82, \mathrm{SD}=1.05)$. However, writing essays, reports and research papers are important tasks in academic writing for EFL undergraduate students [23]. These results seem to be inconsistent with the content of writing syllabus of this department which requires students to study the structure of essay and write different types of essays during their third and fourth semester. A possible explanation for these results might be that the teachers of writing at the department had just explained the structure of essay to their students and discussed the different types of essay with them without asking them to write essays and reports. Another possible explanation for these results is that the teachers did not give much interest in reading and giving feedback on students essay and reports because these tasks need extra time and effort from the teachers. These results might also be explained by that the teachers of the department might encounter some difficulties to teach the essay in their classrooms because students' level in writing could be weak to do so. Orafi and Borg (2009) stated that students' low level of English cause problems to teachers as they organise any oral communicative or writing activities. It is evidently clear from the findings that the assessment system employed by the teachers fail to assess the students writing skills because these students' competences in writing were low for their academic level. The student participants were at the fifth semester, and they were expected to write not only sentences and paragraphs, but also essays and doing other writing activities, such as summarizing articles and writing reports.

Table-2: Writing Tasks Students Performed

\begin{tabular}{|l|l|l|l|l|}
\hline Writing Tasks & M & SD & N \\
\hline 1 & Writing different types of sentences & 3.96 & 0.99 & 28 \\
\hline 2 & Writing different types of paragraphs & 3.64 & 1.28 & 28 \\
\hline 3 & Writing different types of essays & 1.82 & 0.9 & 28 \\
\hline 4 & Writing formal and informal letters & 2.5 & 1.31 & 28 \\
\hline 5 & Writing CVs & 2.85 & 1.5 & 28 \\
\hline 6 & Writing reports & 1.82 & 1.05 & 28 \\
\hline 7 & Summarizing articles & 2.28 & 1.48 & 28 \\
\hline
\end{tabular}

\section{Students' Writing Skills Needed to be supported}

The students were also asked to indicate the degree of need they felt regarding academic writing skills on a five-point scale. Table 3 illustrates that developing the content of their written texts $(M=4$, $\mathrm{SD}=1.05)$, writing well-structured sentences $(\mathrm{M}=4$, $\mathrm{SD}=1.15)$ and choosing the appropriate words $(\mathrm{M}=4$, $\mathrm{SD}=1.12$ ) were the most students' academic writing skills need to be supported. It also displays that students needed support to develop the style of their writing $(\mathrm{M}=3.92, \mathrm{SD}=1.18)$, plan their writing $(\mathrm{M}=3.92$, $\mathrm{SD}=1.3$ ), consider the purpose and audience of their writing $(\mathrm{M}=3.75, \mathrm{SD}=1.2)$, use proper connections and transitions between ideas, sentences and paragraphs
$(\mathrm{M}=3.64, \quad \mathrm{SD}=1.16)$, use correct punctuation and spelling $(\mathrm{M}=3.6, \quad \mathrm{SD}=1.1)$ and avoid plagiarism $(\mathrm{M}=3.53, \mathrm{SD}=1.2)$. These results suggest that the students need support to develop the main aspects of writing which are content, organization, vocabulary, grammar and mechanics. Furthermore, the students need help to improve the other important writing skills, such as planning their writing, considering the purpose and audience of their writing and avoid plagiarism. These findings reveal the students' lack of the necessary writing skills that enable them to produce high quality written texts. 
Osama Albashir Jamoom., Sch Int J Linguist Lit, Apr, 2021; 4(4): 106-111

These results are nearly in line with those of Toba et al., [26] who found EFL Indonesian students enrolled in academic writing course had problems with writing aspects including content, organization, vocabulary, grammar, and mechanics. However, they different from those of [23] which are that Hong Kong undergraduate students needed to develop their lexical and grammatical skills more than developing the content and structure of their written texts. This inconsistency might be attributed to that Hong Kong students were exposed to various academic written texts before entering to university while EFL students in
Libya were not exposed to such texts during their study at the secondary schools.

According to these results, it can be inferred that students had scant knowledge of the writing aspects and they might not exposed to these necessary aspects of writing in their previous writing courses. These results might be attributed to the lack of writing practice and insufficient time allotted to the writing course. The students' needs to develop all of their writing skills might also be due to the ineffective teaching methods and the inappropriate instructional materials used by teachers in their writing classrooms.

Table-3: Students' Writing Skills Needed to be supported

\begin{tabular}{|c|c|c|c|c|}
\hline \multicolumn{2}{|c|}{ Writing Skills } & $\mathbf{M}$ & SD & $\mathbf{N}$ \\
\hline 1 & Planning my writing (analyze the title wording, brainstorm the topic, prepare an outline) & 3.92 & 1.3 & 28 \\
\hline 2 & $\begin{array}{l}\text { Organizing my written work (paragraphs, topic and support, conclusion, coherence, } \\
\text { cohesion, unity) }\end{array}$ & 3.64 & 1.25 & 28 \\
\hline 3 & Writing well-structured sentences (Syntax) & 4 & 1.15 & 28 \\
\hline 4 & Choosing the appropriate words (vocabulary) & 4 & 1.12 & 28 \\
\hline 5 & Using proper grammar & 3.64 & 1.06 & 28 \\
\hline 6 & Using proper connections and transitions between ideas, sentences and paragraphs & 3.64 & 1.16 & 28 \\
\hline 7 & Using correct punctuation and spelling (Mechanics) & 3.6 & 1.1 & 28 \\
\hline 8 & $\begin{array}{l}\text { Developing the content of my written work (argument and ideas, relevance, clarity, } \\
\text { originality, logic) }\end{array}$ & 4 & 1.05 & 28 \\
\hline 9 & Developing the style of my writing & 3.92 & 1.18 & 28 \\
\hline 10 & Considering the purpose and audience of my writing & 3.75 & 1.2 & 28 \\
\hline 11 & Avoiding plagiarism (How to quote, cite, paraphrase and summarize) & 3.53 & 1.2 & 28 \\
\hline
\end{tabular}

\section{CONCLUSION}

This study set out to investigate EFL undergraduate students' needs for improving their writing skills. The results of this study show that the students believed that writing is essential skill for their study and their future career. They also reveal that the students need to improve most of their writing skills (organizing their texts, developing their grammar, develop the content and style of their texts and others). Moreover, the students suffer lack of practicing writing in and outside classroom. These results imply that the students might not be taught the necessary writing skills in their previous writing courses and did not do many and various writing activities that contribute in enhancing their writing skills.

Based on the results of this study, some implications are drawn for teachers of writing, for language courses designers and for departments of English. Initially, teachers of writing and course designers, in order to fulfil the undergraduate students writing skills needs, should take into account students' writing skills needs as they set the learning objectives of the writing courses. They need to design and choose the appropriate material that are compatible with the students writing skills needs. This material should engage students to do a wide variety of writing tasks and present them to several interesting topics that motivate them to write.
Furthermore, teachers of writing and course designers are recommended to offer their students writing courses that not only prepare them to write correct grammatical sentences, but also train them to write different types of written texts, such as paragraphs, essays, reports, research papers and others. These courses should also equip students with knowledge and practice for developing grammatical, lexical and stylistic aspects of their writing. Moreover, they should provide students with strategies for improving the structure and the content of their writing texts and educate them about plagiarism and how to avoid it. Another significant contribution of these courses is assisting extending students' knowledge of the writing process (prewriting, drafting, revising and editing) and provide them with activities that train them to complete each stage of the process.

Similarly, the departments of English have significant roles to play for meeting their students' writing needs. One of these roles is organizing seminars and workshops that increase students' awareness of the writing skills, give them time to write and support them in taking their writing seriously and viewing themselves as writers. The departments of English also need to allot enough time of the writing courses to accommodate the students' writing needs. Applying these suggestions and recommendations is likely to promote students 
Osama Albashir Jamoom., Sch Int J Linguist Lit, Apr, 2021; 4(4): 106-111

engagement in writing, support their learning and improve their writing skills as well as boosting their writing confidence.

Two important limitations need to be considered. The first one is that the sample size was relatively small as the study targeted only one group of university students who studied at the Department of English at University of Zawia. The second limitation is that the data of this study were collected by using only one instrument which was the questionnaire. Although, the results of this study cannot be generalized to university students studying at English departments, they can be helpful to those students studying at similar context and have similar needs. More specific and larger-scale studies need to be conducted for investigating students wring needs in different EFL/ESL contexts. These future studies are required to utilize several data collection tools, such as interview and focus group. These studies might provide valuable results that help students meet their writing needs.

\section{REFRENCES}

1. Gillett, A., Hammond, A., \& Martala, M. (2009). Inside track to successful academic writing. Pearson UK.

2. Yasuda, S. (2014). Issues in teaching and learning EFL writing in East Asian contexts: The case of Japan. Asian EFL Journal, 16(4), 150-187.

3. Hyland, K. (2003). Second language writing. Cambridge University Press

4. Graves, K., \& Xu, S. (2000). Designing language courses: A guide for teachers (No. 428 G7.). Boston, MA: Heinle \& Heinle.

5. Dudley-Evans, T., \& St John, M. J. (1998). Developments in ESP: A multi-disciplinary approach (No. 428.007 D849). Cambridge university press.

6. Hyland, K. (2006). English for academic purposes: an advanced resource book. Abingdon: Routledge.

7. West, R. (1994). Needs analysis in language teaching. Language teaching, 27(1), 1-19.

8. Jordan, R. R., \& Jordan, R. R. (1997). English for academic purposes: A guide and resource book for teachers. Cambridge University Press.

9. Byrne, D. (1988). Teaching Writing Skills. Longman. London and New York.
10. Hedge, T. (1988). Writing. Oxford University Press.

11. Raimes, A. (1983). Techniques in Teaching Writing. Oxford University Press. Oxford.

12. Flower, L., \& Hayes, J. R. (1981). A cognitive process theory of writing. College composition and communication, 32(4), 365-387.

13. Tribble, C. (1996). Writing. Oxford University Press.

14. Ivanič, R., \& Camps, D. (2001). I am how I sound: Voice as self-representation in L2 writing. Journal of second language writing, 10(1-2), 3-33.

15. Heaton, J. B. (1988). Writting English language tests.

16. Cumming, A. (1998). Theoretical perspectives on writing. Annual review of applied linguistics, 18, 61-78.

17. Byrne, D. (1988). Teaching Writing Skills. Longman. London and New York.

18. White, R., \& Arndt, V. (1991). Process Writing. Longman. London and New York.

19. Grabe,W., \& Kalan, R. (1996). Theory and Practice of Writing. Longman. London and New York.

20. Long, M. H. (2005). Overview: A rationale for needs analysis and needs analysis research. Second language needs analysis, 1, 16.

21. Anderson, D. F. (1994). A Proactive Model for Training Needs Analysis (Действенная модель для анализа потребностей в тренинге). Journal of European Industrial Training, 18(3).

22. Tomlinson, B. (2011). Materials development in language teaching. Cambridge: Cambridge University Press.

23. Cai, L. J., \& Kong, H. (2013). Students , perceptions of academic writing : a needs analysis of EAP in China. Language Education in Asia, 4 (1), 5-22.

24. Evans, S., \& Green, C. (2007). Why EAP is necessary: A survey of Hong Kong tertiary students. Journal of English for Academic Purposes, 6(1), 3-17.

25. Littlewood, W. (2001). Students' attitudes to classroom English learning: a cross-cultural study. Language teaching research, 5(1), 3-28.

26. Toba, R., Noor, W. N., \& Sanu, L. O. (2019). The Current Issues of Indonesian EFL Students' Writing Skills: Ability, Problem, and Reason in Writing Comparison and Contrast Essay. Dinamika Ilmu, 19(1), 57-73. 